\title{
An econophysics approach to study the effect of BREXIT referendum on European Union stock markets
}

\author{
E.F. Guedes ${ }^{a}$, Paulo Ferreira ${ }^{\text {b,c,d }}$, Andreia Dionísio ${ }^{\mathrm{d}}$, G.F. Zebende ${ }^{\mathrm{e}, *}$ \\ a Department of Statistics, Federal University of Bahia, Bahia, Brazil \\ ${ }^{\mathrm{b}}$ Research Center for Endogenous Resource Valorization, Portalegre, Portugal \\ ${ }^{\mathrm{c}}$ Instituto Politécnico de Portalegre, Portugal \\ d CEFAGE-UE, IIFA, Universidade de Évora, Largo dos Colegiais 2, 7000 Évora, Portugal \\ e State University of Feira de Santana, Bahia, Brazil
}

\section{H I G H L I G H T S}

- The BREXIT referendum is study by DFA method for the Euro zone.

- In general, the referendum did not change efficiency levels significantly.

- We also calculated the $\Delta \rho_{D C C A}$ coefficient, and our results point to $\Delta \rho_{D C C A}<0$.

- This meaning that the UK is more segmented now than in the past.

\section{A R T I C L E I N F O}

Article history:

Received 20 September 2018

Received in revised form 8 January 2019

Available online 24 April 2019

\section{Keywords:}

BREXIT referendum

Interdependence

Market efficiency

Time series

\begin{abstract}
A B S T R A C T
We analyze the auto-correlations of all European Union (EU) indices and the crosscorrelation between the UK stock market and the other EU markets. This analysis took into account the BREXIT referendum, on the 23rd of June 2016 and the entire period was partitioned in two periods, before and after the BREXIT referendum. First of all, we applied the Detrended Fluctuation Analysis method (with the regular and with a sliding windows approach) in order to evaluate market efficiency. In this case, we found that in general the referendum did not change efficiency levels significantly. With the main purpose of measuring the markets interdependence in relation to the UK index, following the referendum, we calculated the $\Delta \rho_{D C C A}$ coefficient. Our results point to a decrease in the cross-correlation coefficient $\left(\Delta \rho_{D C C A}<0\right)$, meaning that the UK is more segmented now, in relation to other EU partners, than in the past. With $\Delta \rho_{D C C A}$ it was possible to identify how much the referendum influenced the interdependence, but not the efficiency, of European markets.
\end{abstract}

(c) 2019 Elsevier B.V. All rights reserved.

\section{Introduction}

On the 23rd of June 2016, when UK citizens decided to leave the European Union (EU), in the referendum known as BREXIT, financial markets reacted immediately. For example, the main UK stock market, FTSE-100, fell more than 3,1\% on the following day, while the pound/euro exchange rate dropped by more than $7 \%$ in just one week. The future of the UK economy has remained uncertain since then, with many concerns about the evolution of the UK s macroeconomic variables, see [1-4], or the recent opinion [5].

\footnotetext{
* Corresponding author.

E-mail address: gfzebende@hotmail.com (G.F. Zebende).
} 